\title{
Malignancies in HIV/AIDS patients attending an outpatient clinic in Vitória, State of Espírito Santo, Brazil
}

\author{
Lauro Ferreira da Silva Pinto Neto ${ }^{[1]}$, Maria da Conceição Milanez ${ }^{[2]}$, Jonathan Eric Golub ${ }^{[3]}$ \\ and Angelica Espinosa Barbosa Miranda ${ }^{[4]}$
}

[1]. Departamento de Clínica Médica, Escola Superior de Ciências, Santa Casa de Misericórdia de Vitória, Vitória, ES. [2]. Departamento de Patologia, Escola Superior de Ciências, Santa Casa de Misericórdia de Vitória, Vitória, ES. [3]. Division of Infectious Diseases and Bloomberg School of Public Health; Johns Hopkins University, Baltimore, MD, USA. [4]. Departamento de Medicina Social, Universidade Federal do Espírito Santo, Vitória, ES.

\section{ABSTRACT}

Introduction: The present study investigated cancer prevalence and associated factors among HIV-infected individuals attending an AIDS outpatient clinic in Vitória, State of Espírito Santo, Brazil. Methods: A sectional study was conducted among HIV infected adults attending an AIDS outpatient clinic in Vitória, State of Espírito Santo, Brazil. Demographic, epidemiological and clinical data were abstracted from medical records, including cancer diagnoses; nadir and current CD4 cell count, HIV viral load, time on antiretroviral treatment (ART), type of ART and smoking status. Results: A total of 730 (91.3\%) patients were included in the study. Median age was 44.0 [interquartile range (IQR): 35-50.3] years; median time since HIV diagnosis was 5.5 years (IQR: 2-10); $60 \%$ were male; and 59\% were white. Thirty (4.1\%) cases of cancer were identified of which 16 (53\%) were AIDS defining cancers and 14 (47\%) were non-AIDS defining malignancies. Patients diagnosed with cancer presented higher chance of being tobacco users [OR 2.2 (95\% Cl: $1.04-6.24)$ ]; having nadir CD4 $\leq 200$ cells $/ \mathrm{mm}^{3}$ [OR 3.0 $(95 \% \mathrm{Cl}: 1.19-7.81)]$ and higher lethality [OR $13,3(95 \% \mathrm{Cl}: 4,57-38,72)]$. Conclusions: These results corroborate the importance of screening for and prevention of non-AIDS defining cancers focus in HIV-infected population, as these cancers presented with similar frequency as AIDS defining cancers.

Keywords: HIV/AIDS. Malignancies. Prevalence. Brazil.

\section{INTRODUCTION}

Antiretroviral therapy (ART) for human immunodeficiency virus (HIV)-infected patients has improved survival while leading to increasing clinical interest in long-term morbidities in this population. Besides some adverse effects of $A \mathrm{RT}^{1}$, patients are living longer, and new focus on aging diseases as cancer has emerged. Historically, Kaposi sarcoma (KS), non-Hodgkin lymphoma (NHL) and cervical cancer accounted for a substantial proportion of the morbidity and mortality in HIV-infected patients, and are considered acquired immunodeficiency syndrome (AIDS)-defining events ${ }^{2}$. These cancers are mainly caused by loss of immune control towards oncogenic viruses, specifically herpes virus, Epstein Barr virus and human papillomavirus, respectively. Compared with the general population, HIV-infected individuals are at increased risk for each of these diseases ${ }^{3}$, though the widespread use of ART since the mid-1990s led to a significant decline in the incidence of the $\mathrm{KS}$ and $\mathrm{NHL}^{4,5}$. Besides better HIV control through ART, changes in human herpes virus-8 epidemiology may also explain the dramatic decline in number of KS cases $^{6}$. However, despite an overall decline in cervical cancer incidence, numbers among women with AIDS are not declining ${ }^{7}$, although an ongoing, multicenter, prospective cohort of HIV-seropositive women and at-risk HIV-uninfected women in the United States (US) has shown that the incidence of invasive cervical cancer was not significantly higher in HIV-positive women when compared to the uninfected ${ }^{8}$.

Address to: Dr. Lauro Ferreira da Silva Pinto Neto. Depto Clínica Médica/EMESCAM. Rua Dr. João Santos Neves 143, 29019-180 Vitória, ES, Brazil.

Fax: 5527 3212-7200.

e-mail: lauro.neto@emescam.br

Received in 06/07/2012

Accepted in 19/09/2012
In the ART era, increased morbidity and mortality from several non-AIDS-defining malignancies (NADM) have also been reported in HIV-infected population ${ }^{3,9,10}$. A meta-analysis using standardized incidence ratios from 18 studies of NADM in HIV-infected people has shown that HIV-positive individuals had twice the risk of a NADM than the general population ${ }^{11}$. They also reported that the risk of NADM was greater among men and those with full-blown AIDS.

Several factors may contribute to the significant increase in NADM. The size of the HIV-infected population has increased in the last decades in the US from 1991-1995 to 2001-2005'. Furthermore, the incidence of most cancers increases with age, and there is a rising proportion of people with AIDS over 40 years of age nowadays. Cigarette smoking is also more common among HIV-infected individuals than the general population ${ }^{12}$ and may contribute to the rising incidence of lung cancer. Moreover, immunodeficiency in the presence of other risk factors is responsible for the increased risk of NADM, which since 2003 exceeds the annual numbers of AIDS defining cancers in US ${ }^{7}$. However, there have been few reports of cancer and HIV in Brazil ${ }^{13,14,15,16}$. Thus, the aim of this study was to report the prevalence of cancer and its associated factors among HIV-infected individuals attending an AIDS outpatient clinic in Vitória, State of Espírito Santo, Brazil.

\section{METHODS}

A sectional study was performed among adult HIV-1 infected patients (18 years and older) attending an HIV Outpatient Clinic at Santa Casa de Misericórdia de Vitória, State of Espírito Santo, Brazil, between July 2010 and May 2011. All patients were invited to participate in the study. This clinic is the second largest Specialized Assistance Service (SAS) in the City of Vitória, State of Espírito Santo and is part of the national public network providing care for HIV infected patients in Brazil. Demographic, epidemiological and clinical 
data including diagnostic of cancer, lethality, nadir and current cluster of differentation (CD4) cell count, HIV viral load, time on and type of ART and smoking (>20 cigars per day) were collected from all patients at time of cancer diagnosis. All cancer cases were confirmed by histological exams and followed by the oncologist.

Data were analyzed using Statistical Package for the Social Sciences (SPSS), version 17 for Windows (Chicago, IL, USA). Standard descriptive analyses were performed including frequency distributions for categorical data and calculation of medians and interquartile ranges for continuous variables. Univariate odds ratios and $95 \%$ confidence limits were reported. Variables that were significant at $p<0.15$ in bivariate analysis, and known confounders (e.g., age and gender), were considered in the multivariate model using a stepwise multiple logistic regression approach.

\section{Ethical considerations}

Prior to its implementation, the study protocol was submitted and approved by the Ethical Committee for Research of the Escola Superior de Ciências da Santa Casa de Misericórdia da Vitória, State of Espírito Santo.

\section{RESULTS}

A total of $730(91.3 \%)$ cases were included in the study from the total of 800 patients attending the clinic in the period. The remaining 70 patients had missed their scheduled follow up consults during the study period, or were transferred to another clinic nearest to their residence. Median age was 44.0 [interquartile range (IQR): 35.0-50.3] years old, $441(60 \%)$ were males and $430(59 \%)$ were Caucasian. The median time since HIV diagnosis was 5.5 years (IQR: 2-10), 638 (87\%) were on ART according to Brazilian guidelines and 478 (70\%) patients had a HIV viral load below 50 copies/ml. Lethality was more frequent among cancer patients $(23.3 \% \times 1.9 \%, \mathrm{p}<0,001)$.

The most frequently prescribed nucleoside reverse transcriptase inhibitor (NRTI) backbone was lamivudine-zidovudine, used by 350 (48\%) patients followed by lamivudine-tenofovir used by $284(39 \%)$. A total of $47 \%$ used boosted protease inhibitors followed by non-nucleoside reverse transcriptase inhibitors in $41 \%$ of patients.

Table 1 shows demographic, behavioral and clinical characteristics of HIV patients, stratified by cancer status. Patients with cancer were more likely to be tobacco users ( $53.3 \%$ vs. $32.6 \%, p=0.018$ ) and had a nadir CD4 $\leq 200$ cells $/ \mathrm{mm}^{3}$ ( $80 \%$ vs. $50.7 \%, p=0.003$ ).

Thirty (4.1\%) cases of cancer were identified: sixteen (53\%) were AIDS-defining cancer (ADC) and 14 (46.7\%) were NADM (Table 2). All three cases of patients with Non Hodgkin Lymphomas (NHL) had diffuse large B cell lymphoma and none had primary brain NHL. All patients with KS and cervical cancer remain alive.

In the final model of multivariate analysis, factors associated with cancer in HIV patients were being tobacco users [odds ratios - OR 2.2 (95\% confidence interval - $\mathrm{Cl}$ : 1.04-6.24)]; and having nadir CD4 $\leq 200$ cells $/ \mathrm{mm}^{3}$ [OR 3.0 (95\% Cl: 1.19-7.81)] (Table 3). When it was considered only NADM, age older than 50 [OR 16.4 (95\% Cl: 3.3-80.5), $\mathrm{p}=0.001$ ] was added to the logistic model being associated with higher chance of cancer (data not showed).
TABLE 1 - Demographic, behavioral and clinical characteristics of HIV patients, by cancer frequency, attending a specialized clinic in Vitória, State of Espírito Santo, Brazil $(n=730)$.

\begin{tabular}{|c|c|c|c|c|c|}
\hline \multirow[b]{2}{*}{ Variables } & \multicolumn{2}{|c|}{ Cancer $(n=30)$} & \multicolumn{2}{|c|}{ No cancer $(n=700)$} & \multirow[b]{2}{*}{$P$ value } \\
\hline & $n$ & $\%$ & $n$ & $\%$ & \\
\hline \multicolumn{6}{|l|}{ Age in years } \\
\hline $18-49$ & 18 & 60.0 & 513 & 73.3 & 0.110 \\
\hline 50 or older & 12 & 40.0 & 187 & 26.7 & \\
\hline \multicolumn{6}{|l|}{ Gender } \\
\hline male & 20 & 66.7 & 421 & 60.1 & 0.474 \\
\hline female & 10 & 33.3 & 279 & 39.9 & \\
\hline \multicolumn{6}{|l|}{ Schooling } \\
\hline up to 8 years & 9 & 30.0 & 161 & 23.0 & 0.374 \\
\hline more than 8 years & 21 & 70.0 & 539 & 77.0 & \\
\hline \multicolumn{6}{|l|}{ Tobacco use } \\
\hline yes & 16 & 53.3 & 228 & 32.6 & 0.018 \\
\hline no & 14 & 46.7 & 472 & 67.4 & \\
\hline \multicolumn{6}{|l|}{ Time since HIV diagnosis } \\
\hline up to 5 years & 11 & 36.7 & 348 & 49.7 & 0.374 \\
\hline $5.1-10$ years & 10 & 33.3 & 182 & 26.0 & \\
\hline more than 10 years & 9 & 30.0 & 170 & 24.3 & \\
\hline \multicolumn{6}{|l|}{ Nadir CD4 } \\
\hline$>200$ cells $/ \mathrm{mm}^{3}$ & 6 & 20.0 & 345 & 49.3 & 0.003 \\
\hline$\leq 200$ cells $/ \mathrm{mm}^{3}$ & 24 & 80.0 & 355 & 50.7 & \\
\hline \multicolumn{6}{|l|}{ Viral load } \\
\hline undetectable & 18 & 60.0 & 485 & 69.3 & 0.403 \\
\hline detectable & 12 & 40.0 & 215 & 30.7 & \\
\hline \multicolumn{6}{|l|}{ ART } \\
\hline yes & 30 & 100.0 & 608 & 86.9 & 0.024 \\
\hline no & 0 & 0.0 & 92 & 13.1 & \\
\hline \multicolumn{6}{|l|}{ Hepatitis B } \\
\hline yes & 3 & 0.4 & 19 & 2.6 & 0.057 \\
\hline no & 27 & 3.7 & 681 & 93.3 & \\
\hline \multicolumn{6}{|l|}{ Lethality } \\
\hline yes & 7 & 23.3 & 13 & 1.9 & 0.001 \\
\hline no & 23 & 76.7 & 687 & 98.1 & \\
\hline
\end{tabular}

HIV: : human immunodeficiency virus; CD4: cluster of differentiation 4; ART: antiretroviral therapy.

TABLE 2 - Cases of neoplasias diagnosed among HIV patients attending a specialized clinic in Vitória, State of Espírito Santo, Brazil, disposed by gender ( $n=30)$.

\begin{tabular}{lrrrrrr}
\hline \multirow{2}{*}{ Neoplasia } & \multicolumn{2}{c}{ Male } & & \multicolumn{2}{c}{ Female } \\
\cline { 2 - 3 } \cline { 6 - 7 } Kaposi sarcoma & $\mathrm{n}$ & $\%$ & & $\mathrm{n}$ & $\%$ \\
Cervical cancer & 5 & 27.8 & & 2 & 16.7 \\
Non Hodgkin lymphoma & - & - & & 5 & 41.7 \\
Hepatocellular carcinoma & 2 & 11.1 & & 2 & 16.7 \\
Prostate adenocarcinoma & 2 & 11.1 & & - & - \\
Lung carcinoma & 3 & 16.7 & & - & - \\
Hodgkin lymphoma & 2 & 11.1 & & 1 & 8.3 \\
Laryngeal carcinoma & 1 & 5.6 & & 1 & 8.3 \\
Renal carcinoma & 1 & 5.6 & & - & - \\
Colon adenocarcinoma & 1 & 5.6 & & - & - \\
Penis carcinoma & - & - & & 1 & 8.3 \\
\hline Total & 1 & 5.6 & & - & - \\
\hline
\end{tabular}

HIV: human immunodeficiency virus. 
TABLE 3 - Multivariate analysis of factors associated with cancer in HIV patients attending a specialized clinic in Vitória, State of Espírito Santo, Brazil.

\begin{tabular}{lrcc}
\hline Variables & OR & $95 \% \mathrm{Cl}$ & p value \\
\hline Age ( $>50$ vs. $\leq 50$ years) & 1.7 & $0.76-3.83$ & 0.200 \\
Gender (male vs. female) & 1.3 & $0.54-2.91$ & 0.597 \\
Tobacco use (yes vs. no) & 2.2 & $1.04-6.24$ & 0.048 \\
Nadir CD4 ( $\leq 200$ vs. $>200)$ & 3.0 & $1.19-7.81$ & 0.021 \\
Lethality (yes vs. no) & 13.3 & $4.57-38.72$ & 0.000 \\
\hline
\end{tabular}

HIV: human immunodeficiency virus; OR: odds ratio; $95 \% \mathrm{Cl}$ : $95 \%$ confidence interval; CD4: cluster of differentiation 4 .

\section{DISCUSSION}

Cancers reported among HIV-infected patients in our AIDS outpatient clinic in Brazil were practically equally distributed between AIDS defining cancers and non-AIDS defining cancers. The distribution and nature of the samples as well as the study design (cross-sectional) were not the most suitable to make inferences about the cause and effect. However, as the response rate was high, the finding of this study can be generalizable to AIDS patients attending outpatient clinics for HIV in Brazil.

Although in the ART era ADC rates are falling, these cancers still remain highly prevalent in HIV-infected patients. Despite decreases in mortality for AIDS-defining Cancers, NHL remains the most common cancer-related cause of death in the ART era ${ }^{17}$. HIV-infected women should be regularly screening for cervical cancer ${ }^{7}$. Several trials are ongoing to determine if human papilloma virus (HPV) vaccines are effective in HIV-infected men and women ${ }^{18}$, but the actual efficacy of the two currently available HPV vaccines has not yet been demonstrated among HIV young people.

Almost half of our cases of cancer were non-AIDS-defining malignancies. No significant difference was found when the two groups with cancer were compared perhaps because of the small number of cases. Two patients with liver cancer were hepatitis C virus (HCV) coinfected and two patients with Hodgkin lymphoma had mixed cellularity subtype (most common in HIV-infected patients). A study conducted in US showed that lung cancer, liver cancer, and Hodgkin lymphoma represented almost $50 \%$ of all NADM in the AIDS population compared with $16 \%$ of cancers in the general population ${ }^{7}$. Lung cancer is the third most common cancer among HIV-infected patients, following only ADC. Tobacco smoking explains part of this increased risk, but a study of a cohort of injection drug users in Baltimore supports HIV as an independent risk factor for lung cancer ${ }^{19}$. Hodgkin Lymphoma is around 10 times more frequent among HIV-infected people, especially among individuals with moderate immunosuppression ${ }^{20}$.

Hepatocellular carcinoma, clearly linked to hepatitis $C$ and hepatitis B co-infections among HIV-infected patients, was not frequently observed before the ART era because infected patients could not survive long enough to permit this clinical presentation ${ }^{21}$. A prospective observational cohort observed that the incidence of liver cancer was 7.7 fold higher in HIV-infected persons compared to the US general population 22 .

We found a higher chance of cancer with both nadir and current CD4 cell counts lower than 200, and heavy smoking habit was associated with both ADM and NADM. HIV-infected persons tend to smoke more heavily than HIV-negative persons ${ }^{23}$. In both the
Concerted Action on Seroconversion to AIDS and Death in Europe (CASCADE) and the Data Collection on Adverse Events of Anti-HIV Drugs (DAD) cohorts, mortality from NADM also increased as CD4 cell count declined ${ }^{24,25}$. Another prospective cohort reported that current CD4 cell count between 300 and 499 was the most predictive risk factor for all malignancies apart from anal cancer ${ }^{26}$. HIV-related cancers may decline with recent recommendations to initiate ART earlier following HIV diagnosis and at higher CD4 counts ${ }^{27}$.

Our results showed that HIV patients with cancer present a worse prognosis and are dying earlier when compared to HIV patients without cancer. We emphasized the need to focus on several measures necessary to prevent cancer. First, we need to encourage patients to quit smoking. Psychology support, nicotine patches and available drugs would be necessary to assist those on need at the public network. As late-stage lung cancers have and extremely poor prognosis, screening for lung cancer in high risk individuals is necessary. A large randomized control trial compared the use of low-dose computed tomography (CT) scanning with chest radiographs and it was stopped earlier because of findings showing $20 \%$ less mortality benefit in the CT $\mathrm{arm}^{28}$.

Vaccination for hepatitis $B$, alcohol use control and early treatment for hepatitis $C$ are necessary to prevent liver cancer. Liver ultrasonography every 6-months (or at least yearly) is strongly advocated in groups at high risk for hepatocellular carcinoma ${ }^{29}$.

Some controversy exists about the incidence of prostate and colorectal cancer in people with AIDS. Several reports, ${ }^{3,5,21}$ suggest decreased risk for these cancers among HIV-infected people compared with the general population. However, Shiels et al observed a significant increase in incidence rates of prostate cancer in the HIV-infected population in the US ${ }^{6}$, which could reflect an increase in prostate cancer screening and an aging AIDS population in the ART era. All our three cases of prostate cancer were among men over 50 years of age.

Our finding highlights the importance of preventing and promptly treating cancer cases in AIDS patients. These patients must be screened annually for early detection of any kind of cancer to provide early treatment and follow-up due to the increasing rate of cancer in this population.

\section{ACKNOWLEDGMENTS}

We would like to thank the International Clinical, Operational, and Health Services Research and Training Award (ICOHRTA) Program, the Fogarty International Center/US National Institutes of Health \#U2RTW006885 ICOHRTA-NIH Al066994 for grant support.

\section{CONFLICT OF INTEREST}

The authors declare that there is no conflict of interest.

\section{ABSTRACT IN PORTUGUESE}

\section{Câncer em pacientes com HIV/AIDS atendidos em clínica ambulatorial em Vitória, Estado do Espírito Santo, Brasil}

Introdução: 0 presente estudo investigou a prevalência de câncer e fatores associados entre pacientes infectados pelo vírus HIV em clínica de AIDS em Vitória, Estado do Espírito Santo, Brasil. Métodos: Um estudo transversal foi conduzido entre pacientes HIV positivos adultos atendidos em serviço 
especializado em AIDS, em Vitória, Estado do Espírito Santo, Brasil. Dados demográficos, epidemiológicos e clínicos foram coletados de prontuários, inclusive diagnóstico de câncer, contagem de CD4 corrente e a mais baixa, carga viral do HIV, tipo e tempo de tratamento antirretroviral, e tabagismo. Resultados: Um total de $730(91,3 \%)$ pacientes foi incluído no estudo. A mediana de idade foi de 44 anos (Diferença Inter Quartil [DIQ]: 35-50,3), a mediana de período desde diagnóstico de HIV foi de 5,5 anos (DIQ: 2-10), $60 \%$ eram homens e $59 \%$ eram brancos. Trinta $(4,1 \%)$ casos de câncer foram identificados, dos quais 16 (53\%) eram neoplasias definidoras de AIDS e 14 (47\%) eram neoplasias não definidoras de AIDS. Pacientes diagnosticados com câncer apresentavam maior chance de serem fumantes [OR 2,2 $(95 \% \mathrm{Cl}$ : 1,04-6,24)], terem nadir de CD4 $\leq 200$ cels $/ \mathrm{mm}^{3}$ [OR 3,0 (95\% Cl: 1,19-7,81)] e maior letalidade [OR 13,3 (95\% Cl: 4,57-38,72)]. Conclusões: Estes resultados corroboram a necessidade de rastreamento e prevenção de neoplasias não definidoras de AIDS em nossa população infectada pelo HIV, já que estas já assumem frequência similar às definidoras de AIDS.

Palavras-chaves: HIV/SIDA. Câncer. Prevalência. Brasil.

\section{REFERENCES}

1. Segatto AFM, Freitas Jr IF, Santos VR, Alves KCP, Barbosa DA, Portelinha Filho AM, et al. Lipodystrophy in HIV/AIDS patients with different levels of physical activity while on antiretroviral therapy. Rev Soc Bras Med Trop 2011; 44:420-424.

2. Centers for Disease Control and Prevention. 1993 revised classification system for HIV infection and expanded surveillance case definition for AIDS among adolescents and adults. MMWR Morb Mortal Wkly Rep 1992; 41(RR-17):1-19.

3. Grulich AE, van Leeuwen MT, Falster MO, Vajdic CM. Incidence of cancers in people with HIV/AIDS compared with immunosuppressed transplant recipients: a metaanalysis. Lancet 2007; 370:59-67.

4. International Collaboration on HIV, Cancer. Highly active antiretroviral therapy and incidence of cancer in human immunodeficiency virus-infected adults. J Natl Cancer Inst 2000; 92:1823-1830.

5. Engels EA, Pfeiffer RM, Goedert JJ, Virgo P, McNeel TS, Scoppa SM, et al. Trends in cancer risk among people with AIDS in the United States 1980-2002. AIDS 2006; 20:1645-1654.

6. Eltom MA, Jemal A, Mbulaiteye SM, Devesa SS, Biggar RJ. Trends in Kaposi's sarcoma and non-Hodgkin's lymphoma incidence in the United States from 1973 through 1998. J Natl Cancer Inst 2002; 94:1204-1210.

7. Shiels MS, Pfeiffer RM, Gail MH, Hall HI, Li J, Chaturvedi AK, et al. Cancer burden in the HIV-infected population in the United States. J Natl Cancer Inst 2011; 103:753-762

8. Massad LS, Seaberg EC, Watts DH, Minkoff H, Levine AM, Henry D, et al. Longterm incidence of cervical cancer in women with human immunodeficiency virus. Cancer 2009; 115:524-530.

9. Pantanowitz L, Schlecht HP, Dezube BJ. The growing problem of non-AIDS-defining malignancies in HIV. Curr Opin Oncol 2006; 18:469-478.

10. Powles T, Robinson D, Stebbing J, Shamash J, Nelson M, Gazzard B, et al. Highly active antiretroviral therapy and the incidence of non-AIDS-defining cancers in people with HIV infection. J Clin Oncol 2009; 27:884-890.

11. Shiels MS, Cole SR, Kirk GD, Poole C. A meta-analysis of the incidence of non-AIDS cancers in HIV-infected individuals. J Acquir Immune Defic Syndr 2009; 52:611-622.
12. Tesoriero JM, Gieryic SM, Carrascal A, Lavigne HE. Smoking among HIV positive New Yorkers: prevalence, frequency, and opportunities for cessation. AIDS Behav 2010; 14:824-835.

13. Andrade AC, Luz PM, Veloso VG, Cardoso SW, Moreira RI, Grinsztejn B, et al. Breast cancer in a cohort of human immunodeficiency virus (HIV)-infected women from Rio de Janeiro, Brazil: a cases series report and an incidence rate estimate. Braz J Infec Dis 2011; 15:387-393.

14. Silva IT, Araújo JR, Andrade RV, Cabral CR, Gimenez FS, Guimarães AG, et al. Anal cancer precursor lesions in HIV-positive and HIV-negative patients seen at a tertiary health institution in Brazil. Acta Cir Bras 2011; 26:64-71.

15. Sampaio J, Brites C, Araujo I, Bacchi CE, Dittmer DP, Tanaka PI, et al. AIDS related malignancies in Brazil. Curr Opin Oncol 2007; 19:476-478.

16. Micheletti AR, Macedo AC, Silva GB, Silva AC, Silva-Vergara ML, Murta EF, et al. Benign and malignant neoplasias in 261 necropsies for HIV-positive patients in the period of 1989 to 2008. Rev Inst Med Trop Sao Paulo 2011; 53:309-314.

17. Diamond C, Taylor TH, Aboumrad T, Anton-Culver H. Changes in acquired immunodeficiency syndrome-related non-Hodgkin lymphoma in the era of highly active antiretroviral therapy: incidence, presentation, treatment, and survival. Cancer 2006; 106:128-135.

18. Heard I. Human papillomavirus, cancer and vaccination. Curr Opin HIV AIDS 2011; 6:297-302.

19. Kirk GD, Merlo C, O' Driscoll P, Mehta SH, Galai N, Vlahov D, et al. HIV infection is associated with an increased risk for lung cancer, independent of smoking. Clin Infect Dis 2007; 45:103-110.

20. Carbone A, Gloghini A, Serraino D, Spina M. HIV-associated Hodgkin lymphoma. Curr Opin HIV AIDS 2009; 4:3-10.

21. Sulkowski M. Hepatocellular carcinoma in HIV-infected patients comes of age: The convergence of epidemiology and treatment effectiveness. J Hepatol 2009; 50:655-658.

22. Patel P, Hanson DL, Sullivan PS, Novak RM, Moorman AC, Tong TC, et al. Incidence of types of cancer among HIV-infected persons compared with the general population in the United States, 1992-2003. Ann Intern Med 2008; 148:728-736.

23. Saves M, Chene G, Ducimetiere P, Leport C, Le Moal G, Amouyel P, et al. Risk factors for coronary heart disease in patients treated for human immunodeficiency virus infection compared with the general population. Clin Infect Dis 2003; 37:292-298.

24. Smit C, Geskus R, Walker S, Sabin C, Coutinho R, Porter K, et al. Effective therapy has altered the spectrum of cause-specific mortality following HIV seroconversion. AIDS 2006; 20:741-749.

25. Monforte A, Abrams D, Pradier C, Weber R, Reiss P, Bonnet F, et al. HIV-induced immunodeficiency and mortality from AIDS-defining and non-AIDS-defining malignancies. AIDS 2008; 22:2143-2153.

26. Guiguet M, Boue F, Cadranel J, Lang JM, Rosenthal E, Costagliola D, et al. Effect of immunodeficiency, HIV viral load, and antiretroviral therapy on the risk of individual malignancies (FHDH-ANRS CO4): a prospective cohort study. Lancet Oncol 2009; 10:1152-1159

27. Grulich AE. Living longer with HIV: what does it mean for cancer risk? Curr Opin HIV AIDS 2009; 4:1-2.

28. Sigel K, Dubrow R, Silverberg M, Crothers K, Braithwaite $S$, Justice A. Cancer screening in patients infected with HIV. Curr HIV/AIDS Rep 2011; 8:142-152.

29. Bruix J, Sherman M, Practice Guidelines Committee AAftSoLD. Management of hepatocellular carcinoma. Hepatology 2005; 42:1208-1236. 